\title{
Editorial
}

\section{National Health Systems Response to COVID-19 Outbreak, Iraq an Example}

\author{
Alaa H. Abed ${ }^{1}$, Dhurgham A. Abdulwahid², Haider A. Jassim ${ }^{3}$ \\ ${ }^{1} \mathrm{PhD}$ in Community Medicine, Basra University College of Science and Technology. \\ ${ }^{2}$ CABMS, Specialist in Pediatrics, Member of Iraqi Association of Medical Research and Studies (IAMRS), \\ ${ }^{3}$ FICMS, Specialist in Pediatrics, Al-Basra Specialized Child Hospital and Member of Iraqi Association for Medical Research \\ and Studies (IAMRS)
}

Keywords: COVID-19, Health System, Basrah

Received:20.5.2021

* Correspondence Alaa H. Abed. Basra University College of Science and Technology. Mobile phone \#: 07712631062

$\bowtie \quad$ dralaaabed@gmail.com

Compliance with ethical standards

Conflict of interest the authors declare that they have no conflict of interest.

$\mathrm{T}$ he sudden emergence of the COVID-19 outbreak in December, 2019 Wuhan, China, had an important role in testing the readiness of countries' health systems worldwide, and measuring their efficiency and speed of response. It has become clear how health systems around the world have responded to this pandemic. A number of health systems have collapsed, some have survived, and others have been fluctuating ${ }^{(1)}$. In general, there was a considerable lack/ shortage of preparedness of the countries of the world to respond to such emergencies that a number of scientists had expected years ago (2). Assessing national/ regional health systems' response to crises requires covering several levels, such as governments' response and interaction to the crisis through legislations, general plans and financing; the response and management of health institutions to the crisis according to prepared protocols for crisis management; community
Accepted: 12.6.2021

organizations' response and cooperation in mobilizing efforts to support the health sector; and citizen response and cooperation with health authorities ${ }^{(2)}$.

On March $11^{\text {th }}, 2020$, the World Health Organization (WHO) announced a public health emergency to raise global concern and urged governments to be prepared for the spread of COVID-19 $9^{(3)}$. Most countries, including Iraq, have taken many strict public health measures and had entered in a complete lockdown state, when entry has been restricted through ports, airports and border crossings ${ }^{(4)}$. The WHO standard containment approach of surveillance, testing, treatment and isolation has been adopted and has worked well in some countries ${ }^{(3)}$. The Government of Iraq formed a crisis task force headed by the Minister of Health and the membership of many political figures, but it lacked the presence of public health and epidemics specialists ${ }^{(5)}$. The first cases were recorded in Iraq on February 24, 2020; and as a response to the WHO advice, to consider physical distancing as a preemptive measure to stop the spread of COVID-19 ${ }^{(3)}$, the Crisis Task Force decided to suspend work hours in all schools and universities; in February 26, it decided to shut cinemas, valley, cafes and party halls. On 
The Medical Journal of Basrah University

(2021);39 (1): 1-6

March $3^{\text {rd }}$, it was decided to impose a sevenday curfew, followed by an extension of the ban (6). In comparison to other countries which implemented the lockdown after having large numbers of confirmed cases, Iraq was one among the countries to take lockdown measures very early in response to the epidemic ${ }^{(7)}$. Although the decisionmaking process was not clear, it absolutely was a swift and mandatory decision regarding the shutdown. However, it is very difficult for Iraqis who live in crowded areas to follow physical distancing instructions. After few weeks of alternating total and partial bans, situations got worse and worse. Especially, people started to get bored and worry of the economic and social repercussions of the prolonged curfews. Therefore, the Government began to loosen restrictions and could not follow measures to stop mass gatherings, physical distancing, and other curfew measures strictly.

The human, material, and financial resources of the health system are vital in determining its ability to respond to health emergencies ${ }^{(8)}$. But it seems that successive governments have not sufficiently invested in the health system in Iraq for many years ${ }^{(9)}$. Iraqi health institutions have been struggling to deal with the increasing number of COVID-19 cases, mainly severe ones that needed weeks of medical care in addition to other basic healthcare services (other than COVID-19). This is due to the lack of financial and human resources and poor infrastructure.

At the beginning of the epidemic, there was an acute shortage of personal protective equipment (PPE), testing tools, sanitizers, equipment, supplies, medicines, and health personnel across Iraq with an urgent need to purchase and renew these resources despite their lack of availability ${ }^{(10)}$. Generally, the central decision was in favor of the Iraqi health system. But the complicated social situation and the weakness of the health system led to a shortage in protecting the staff
National Health Systems Response to COVID-19 Outbreak, Iraq an Example in the Iraqi Ministry of Health. This is due to the unavailability of sufficient quantities of personal protective equipment and necessary materials for prevention, contrary to the recommendations of the World Health Organization ${ }^{(10)}$.

For better performance of scientific communities in emergency situations, there is a focus on the central role of researchers. This is supported by a study revealed that researchers have a central role in providing better information to both decision-makers and the public ${ }^{(11)}$.

Basrah Governorate recorded the first cases and deaths in March 2020 ${ }^{(12)}$. Till 1 April 2021 , the total number of infected health workers in Basrah Governorate reached 1391, and the deaths were $38^{(13)}$. Basrah Governorate's response to the COVID-19, according to the central task force, formed its own task force led by politicians and administrators, and it also lacked public health experts and epidemiologists. The epidemic itself causes four problems: health, economic, political and security instability. With the spread of the COVID-19 pandemic, concerns have increased, especially in those countries with fragility and vulnerabilities in social, economic and health systems. The majority of the low-income populations live in poor health systems countries. They are at great risk of more cases, as they chronically suffer from various forms of crises, such as poor administration, poor health services, high rates of poverty, unemployment, high population density, and poor water and sanitation services. There is also a lack/ shortage in the hygiene necessary to prevent and control infection, as the health systems in such countries are poorly equipped and suffer from shortage in primary health care professionals, medications and equipment ${ }^{(14)}$. Iraq is one of those countries that face complex challenges of political instability, security and economic crises, difficult living conditions and poverty ${ }^{(15)}$. In the absence of 
The Medical Journal of Basrah University

(2021);39 (1): 1-6

clear mechanisms and vague governance, it becomes necessary to develop a unified and evidence-based plan at the country level so that governmental and non-governmental offices own a clear transparent exit plan. That means an evidence-based health system and policies strengthening approach is an urgent priority in Iraq. Generally, the role of nongovernmental bodies in the process of decision-making has been very limited, specifically with regard to technical counseling, implementation of preparations, resource mobilization and management measures. However, the role of few nongovernmental organizations, such as the Iraqi Association for Medical Research and Studies (IAMRS), is increasing in health strategy in $\operatorname{Iraq}^{(16)}$. At national level, the formation of the National Supreme Advisory Committee (16 Senior medical specialists) in Early July 2020 was a good development to coordinate scientific advice regarding the COVID-19 pandemic control (17).

Basrah Government after diagnosing the first case, immediately announced the state of emergency and began control measures. These preemptive measures included closing the Governorate by restricting movement and closing most of the unnecessary facilities. Moreover, the Central Government imposed strict closures of borders, non-essential companies, and all educational facilities and religious rituals inside mosques. These measures have been to some extent effective ${ }^{(18)}$. Basrah residents make up about $9 \%$ of the population of Iraq; however, nearly $6.7 \%$ of the total cases in Iraq have been from Basrah $^{(19)(20)}$. The Government has partnered with actors such as Basrah Directorate of Health, Basrah University and nongovernmental organizations, especially the World Health Organization (WHO) and the IAMRS, to support the response efforts for COVID-19 in Iraq. The health authorities in Basrah followed the same approach of centralized instructions, but relatively

http://dx.doi.org/10.33762/mjbu.2021.130218.1071
National Health Systems Response to COVID-19 Outbreak, Iraq an Example

independently. However, there was a need for further clarification and better communication with the population regarding response action plans and their rationale.

What helped in management of the crisis in Basrah was the immediate response of a limited number of donors, such as Basrah University and the Science Camp, who provided some basic diagnostic, treatment and prevention equipment, but this role has needed to be further strengthened.

It becomes clear to us that a national plan to train and support the health workforce in the short and long terms is necessary, as priority is given to the medical specialties required in universities, government employment plans, and training programs are set up at the state level to prevent and combat epidemics, in addition to upgrading the technological capabilities of the health system. These priorities represent real opportunities to Basrah Government and donors to invest in health currently and in the future. Evidencebased planning and decision making are the principles to provide support in strengthening health system in both emergency and normal circumstances. To achieve this, empowering the weak research system in Iraq is the core strategy to assist health system decision makers to make efficient decisions regarding planning, optimal benefiting from resources, monitoring and evaluation ${ }^{(21)}$.

The strategies and efforts need to be more effective, efficient, systematic, integrated and comprehensive to work in different tracks: mobilizing tasks and resources to mitigate and contain control measures of the COVID19 epidemic; establishing a conditional lockdown mitigation system with local and national transmission rates; rethinking about a post-pandemic strategy to strengthen the country health system, considering evidencebased governance, health planning, health information management, updated technology, resource allocation, 
The Medical Journal of Basrah University

(2021);39 (1): 1-6

preparedness planning, and research support policy. That is, implementing COVID-19 control measures is not to flatten epidemiological curves and provide clinical capacity in hospitals, but rather to protect lives and communities at risk.

The above performance, when compared internationally, came at the end of the quality comparison lists. For example, Lowy Institute issued, at the beginning of 2021, a table contains ranked comparison of the average performance over time of countries in managing the COVID-19 pandemic in the 36 weeks following their hundredth confirmed case of the virus. In total, 98 countries were evaluated, based on the availability of data across the six indicators used to construct this Index. Iraq scored $25.2 \%$ and came in the $83^{\text {rd }}$ position out of 98 countries; i.e. it came within the list of the last poorest performance quarter of the list ${ }^{(22)}$. In another assessment process, Iraq healthcare system came at the $87^{\text {th }}$ position according to the 2021 CEOWORLD magazine Health Care Index, which assessed the performance of 89 countries according to factors that contribute to overall health ${ }^{(23)}$.

\section{Conclusion}

According to the international standards, the performance of the Iraqi healthcare system, regarding COVID-19 control or in general, seems to be not competitive but was much better than anticipated at the beginning of the pandemic.

\section{References}

1. Kuguyo O, Kengne AP, Dandara C. Singapore COVID-19 Pandemic Response as a Successful Model Framework for Low-Resource Health Care Settings in Africa? OMICS. 2020 Aug; 24(8):470-478. doi: 10. 1089/omi. 2020. 0077. Epub 2020 Jun 16.
National Health Systems Response to COVID-19 Outbreak, Iraq an Example

2. Wang Z, Duan Y, Jin Y, Zheng ZJ. Coronavirus disease 2019 (COVID19) pandemic: how countries should build more resilient health systems for preparedness and response. Glob Health J. 2020 Dec; 4(4):139-145. doi: 10. 1016/j. glohj. 2020. 12. 001. Epub 2020 Dec 6.

3. World Health Organization. Coronavirus Disease 2019 (COVID19): Situation Report-51. https://apps. who. int/iris/bitstream/handle/10665/3314 75/nCoVsitrep11Mar2020-eng. pdf? sequence $=1$ \&isAllowed $=\mathrm{y}$. Accessed January 30, 2021.

4. Islam N, Sharp SJ, Chowell G, Shabnam S, Kawachi I, Lacey B, Massaro JM,D'AgostinoSr RB, White M. Physical distancing interventions and incidence of coronavirus disease 2019: natural experiment in 149 countries. BMJ. 2020 Jul 15;370:m2743. doi: 10. 1136/bmj. m2743.

5. The Iraqi Ministry of Health official letter number 897 in 19/3/ 2020

6. Decisions of the Iraqi Council of Ministers. Routine Meeting in 3/ 3/ 2020

7. The Guardian. (2020). How coronavirus lockdown compares to other countries. Retrieved April 19, 2020. https://www. The guardian. com/politics/2020/mar/23/how-ukcoronavirus-lockdown-compareswith-other-countries. Accessed on January 10, 2021.

8. World Health Organization (WHO). (2020f). Eastern Mediterranean Region COVID-19 affected countries. https://app. powerbi. com/view? Retrieved May 10, 2020.

9. Aboulenein A and Levinson R. The medical crisis that's aggravating Iraq's unrest. A Reuters Special 
The Medical Journal of Basrah University

(2021);39 (1): 1-6

Report. March 2, 2020. Iraq's healthcare system is in crisis. Patients are suffering. (reuters. com). https://www. reuters. com/investigates/special-report/iraqhealth/. Accessed on January 13, 2021.

10. Mikhaela EM, Al-Jumaili AA. Can developing countries face novel corona virus outbreak alone? The Iraqi situation. Public Health in Practice. 2020 Nov; 1: 100004.

11. AlKhaldi M, Alkaiyat A, Pfeiffer C, Haj-Yahia S, Meghari H, Obaid HA. Mapping stakeholders of the Palestinian health research system: A qualitative study. East Mediterranean Health Journal, 25. 2019a. https://doi. org/10. 26719/emhj. 19.016 [Google Scholar]

12. Basra reports first death due to coronavirus. https://www. kurdistan24. net/en/story/21988Basra-reports-first-death-due-tocoronavirus. Accessed on January 7, 2021.

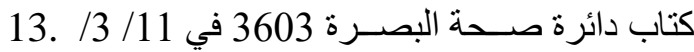
2021. شعبة إدارة الموارد البشرية/ قسم الأمور الإدارية و المالية و القانونية الإنية

14. IRC. How the IRC responds to COVID-19 in Syria and other conflict zones. Retrieved May 9, 2020. https://www. rescue-uk. org/article/how-irc-responds-covid-

19-syria-and-other-conflictzones [Google Scholar]. Accessed on January 13, 2021.

15. Al-Ogaili AAT. Politics and Security in Iraq: Challenges and Opportunities. July 2020. FriedrichEbert-Stiftung, Jordan and Iraq Office Amman, Jordan.

16. الجمعية العر اقية للدار اسات الطبية تطلق 37 بحثنا متخصسصــا بكورونا في البصـرة. راديو المربد الطبد https://www. almirbad.
National Health Systems Response to COVID-19 Outbreak, Iraq an Example

com/detail/47941. Accessed on December 25, 2020.

17. الأمانـة العامـة لمجلس الوزراء. الأامر الديوني

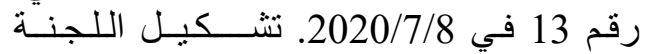

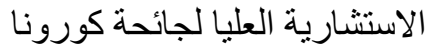

18. Iraq: Authorities implement further measures due to COVID-19 from March 17 /update 13. Garda world. https://www. garda. com/crisis24/newsalerts/323091/iraq-authoritiesimplement-further-measures-due-tocovid-19-from-march-17-update-13. Accessed on January 12, 2021.

19. The Daily Report, SARS-Cov2, Basra Directorate of Health.

20. الموقف الوبائي و التلقيحي اليومي لجائحة كورونا

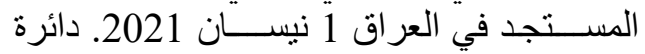

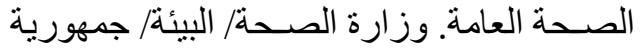
العر اق اق الت

21. AlKhaldi M, Alkaiyat A, AbedY, Pfe iffer C, Halaseh R, Salah R. The Palestinian health research system: Who orchestrates the system, how and based on what? A qualitative assessment. Health Research Policy Systems, 16. 2018. https://doi. org/10. 1186/s12961-018-03474 [Crossref], [Web of Science (]), [Google Scholar]. Accessed on January 13, 2021.

22. Lowy Institute, COVID-19 Performance Index, Deconstructing Pandemic Responses, https://interactives. lowyinstitute. org/features/covid-performance/.

Accessed on March29, 2021

23. Sophie Ireland, Revealed: Countries With The Best Health Care Systems, 2021, Ceoworld Magazine, April 27, 2021. https://ceoworld. biz/2021/04/27/revealed-countrieswith-the-best-health-care-systems2021/ Accessed on April 30, 2021 


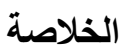

تصف هذه المقالة تطور وباء كوفد-19 في العراق (تحديداً

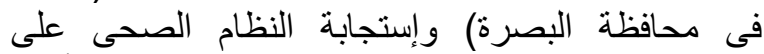
المستوى الوطنى ومستوى المحافظة للسيطرة على النى الأزمة

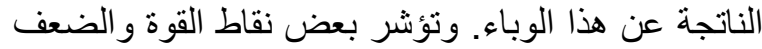

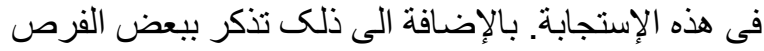

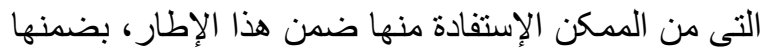

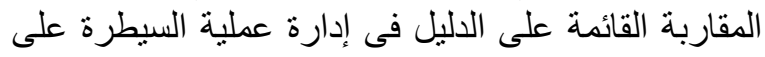

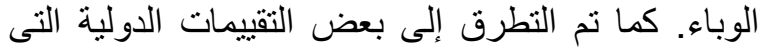

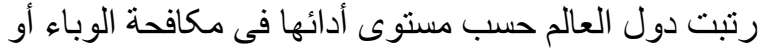

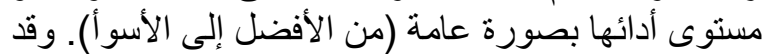

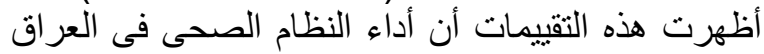

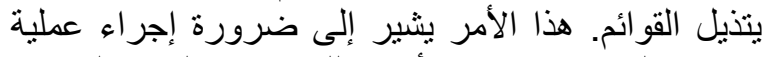

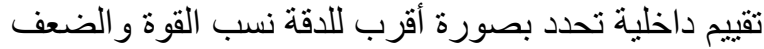
فى أداء هذا النظام. 